\title{
STUDENTS' PERCEPTION ON QUIZZIZ AS GAME BASED LEARNING IN LEARNING GRAMMAR IN WRITTEN DISCOURSE
}

\author{
Afief Fakhruddin $^{* 1}$, Eka Nurhidayat ${ }^{* 2}$ \\ afieffakhruddin@unma.ac.id $^{* 1}$, ekanurhidayat@unma.com ${ }^{* 2}$ \\ Fakultas Keguruan dan Ilmu Pendidikan ${ }^{* 1,2}$ \\ Universitas Majalengka, Majalengka Jawa Barat ${ }^{* 1,2}$
}

\begin{abstract}
The aimed of the research was to investigate students' opinions on Quizizz as Game-Based Learning in learning grammar in Written discourse and their obstaction in the usage. The data for this study was gained through questionnaires and interviews. This research belongs to descriptive qualitative method is suitable to be used in this research. The participants of this research was students of fourth semester of English Department. The instruments of this research were quistionaire and interview. Ten questions were provided by the researcher in which relevant to topics by using Quizizz as games-based learning. The study revealed that the students had a positive perception of quizzes, and all students were very active in answering the questions provided by research and more concentrated on the topic. The study's result contributed to improving EFL teaching and learning activity, especially in learning grammar in Written discourse. The conclusion of this research was most of the students strongly agree that quizziz made students more interest in learning grammar in written discourse.
\end{abstract}

Keywords: Students' perception, Quizziz, game-based learning, and grammar discourse.

DOI : https://doi.org/10.31943/wej.v4i2.101

\section{INTRODUCTION}

Grammar is stated by many experts as a basic knowledge of learning English. It means that grammar is the study of structural relationships in a language or the system of rules implicit in a language, viewed as a mechanism for generating all sentences possible in that language. To understand the communication in a language, we have to use language grammatically, it is because of grammar is the basic rule in a language. If we use language grammatically, it means that we learn language according to the rules of grammar and it will produce good sentences. The existence of language components, such as grammar, vocabularies, spelling and pronunciation are thought as supporting components for the improvement of those skills. They can be taught implicitly and explicitly. It means that the students can improve their language skill because of good learning. Grammar is the structure of language to sort out significance. As far as learning English as a Foreign Language, students must ace explicit information, particularly sentence structure, to have the option to utilize the language appropriately. Students must know whether their sentences utilize the 
right example or not when they talk or compose. They additionally should grasp whether the sentences they tune in to or read is right or not. They should acing language since it is a urgent perspective in English. Smedley (1983: 13) argued that Language study is a significant action in its own privilege as a significant piece of our way of life since it recognizes us as a species. Subsequently, the phonetic examination ought to be a focal piece of instruction and a knowledge into how punctuation capacities ought to be a focal piece of that study. It is the combination of phrases, clauses, or sentences that impact of our language skills. Strumpf and Douglas (2004:14) said that we study sentence structure with the goal that we may talk and compose all the more viably. This implies the understudies must realize how to arrange a right example to limit misconception in sharing thoughts or data. Instructing English language structure has a basic job since it gets one of the principle small scale abilities that must be aced. Considering the expalanation above, it is clear that basically grammar has the same point of view; it is rules of language which show how to deliver a message and produce a good sentence. So the learners will understand the meaning of the messages and the sentence correctly and can use the grammar well in speaking and writing. Grammar and language can't be separated to each other. By using grammar correctly a learner can produce acceptable utterances and sentences. This research is about language, how the role of using English with proper grammatical structure. Sentence structure is expressed by numerous specialists as an essential information on learning English. It implies that punctuation is the investigation of auxiliary connections in a language or the arrangement of rules verifiable in a language, saw as a system for producing all sentences conceivable in that language. To understand the communication in a language we have to use language grammatically, it is because grammar is the basic rule in a language. If we use language grammatically, it means that we learn language according to the rules of grammar and it will produce good sentences.

Joseph Devito (1960), in Hughes (1962:6), language is a system of the arbitrary vocal symbol by which thought is conveyed from one human being to another. It implies that the capacity of language is a mechanism of correspondence and collaboration. One of the significant parts of correspondence is the utilization of words. One of the important aspects of communication is the use of words. Considering the explanation above, this study also tried to reveal students' perception Quizizz as Game-Based Learning as an in learning grammar in Written discourse. According to Robbins \& Judge (2013: 166), perception is a process by which individuals organize and interpret their sensory impressions to give meaning to their environment. Sperling (1982) also affirmed that perception represents peoples' understanding of a present situation in terms of their experience. As indicated by Robbins and Judge (2013: 166), perception is a procedure by which people compose and decipher their tactile impressions to offer significance to their condition. Sperling (1982) additionally confirmed that perception speaks to people groups' comprehension of a current circumstance regarding their experience.

On the other hand, Mussen (1973) states that perception is the way toward obtaining data through tangible receptors that are changed into a view of what we think, see, hear, smell, taste, or contact. People can decipher data in an alternate manner even they get some data with others. It can happen because of elements of 
the circumstance (time, work setting, and social setting), factors in the perceiver (perspectives, thought processes, interests, encounters, and desires) or factors in the objective (curiosity, movement, sounds, size, foundation, vicinity, and similitude). (Robbins \& Judge, 2013:167). In this context, perception affirms students' image of seeing quizzes as an EFL learning application that is used to help them learn grammar in Written discourse.

\section{LITERATURE REVIEW}

Syah (1999:91) stated that learning is the way toward obtaining information and a relatively permanent change in potential responses, resulting in reinforced practice. The statement described that the learning results had permanent while the students responded to the lesson as the result of reinforced practice. Steven (1977: 5) expressed that learning a language is a procedure of getting cognizant control of phonological and syntactic system and encountering to get the substance of language. It means that language learning is acquiring knowledge, especially in phonological strategy and process acquiring the uses of grammar and rules of language done by the student. Brown (1994:7) notes that learning is securing or getting information regarding a matter or an ability by contemplating, having experience, or guidance. It means that language learning is acquiring knowledge, especially in phonological strategy and process acquiring the uses of grammar and rules of language done by the student. Brown (1991:7) expressed that learning is procuring or getting of information regarding a matter or an aptitude by study, understanding, and guidance. Considering the definitions above, learning is a process of acquisition and getting of knowledge while the students follow the teachers' instruction. The result of learning will be permanent when the students practice the lesson continuously.

According to Gagne (1965) in Brown (1994: 81), there are some types of learning:

a. Signal learning

The individual learns to make a general response signal to learn. Signal learning generally occurs in the total language process; humans make a general response of some kinds of emotional cognitive or nonverbal to language.

b. Stimulus-response learning

The learner acquires a precise response to differentiate.

c. Multiples discrimination

The individual learns to make some of the different identifying responses to many different stimuli, which may resemble each other in physical appearance to a greater or lesser degree. Although the learning of each stimulus-response connection is a simple occurrence, the connections tend to interfere with one another.

d. Problem-solving

Problem-solving is a kind of learning that requires internal events, usually referred to as thinking. Previously acquired concepts and principles are combined in conscious an unresolved, or ambiguous set of events. 
From the explanation above, it can be seen there are four types of learning; the first is signal learning, the second is stimulus-response learning, the third is multiples discrimination, and the fourth is problem-solving. Signal learning generally occurs in the total language process: human beings make a general response of some kind emotional, cognitive, verbal, or nonverbal to language. Stimulus responds learning is the acquisition of the sound of the system of a foreign language. Multiple discrimination focuses on identifying responses to different stimuli. In problem-solving, the learner continually faced with a lot of events that truly problems to be solved.

Brown (1980:7) expressed that showing guides and encourages learning movement, empowering the student to learn and set the condition for learning. In the teaching-learning process, the teacher is the central part of that process. It is because the teacher has a big responsibility to deliver the material for the students. This is under the ideas of Brown (1980:70), stating that teaching is showing or helping someone to learn how to do something, giving instruction, guiding in the study of something, providing with knowledge, causing to know or understand. Harfielet.al. in Heaton (1978:90) says that there are some components in writing text or paragraph such as content, organization, vocabulary, language use, and mechanic. Those can be explained as follows:

a. Content skill is the ability to develop and to complete the ideas in composition;

b. Organization skill is the ability to arrange the information logically and fluently;

c. Vocabulary skill is the ability to select words to convey a suitable tone for particular audience and clarity of meaning;

d. Language use skill is the ability to use grammatical principles; such as, agreement, tense, word order etc;

e. Mechanic skill is the ability to use mechanical principles; such as, spelling, punctuation, and capitalization.

Those five components are closely related to each other and can be used as a guide in expressing their thoughts appropriately.

Fadloeli (1986: 11) who says that writing is difficult skill, when we write we seem to communicate into space, we don't know who is receiving the message. It means that we need some points in writing in order to produce a clear and understandable piece of writing for the readers. The points are how to organize what we are going to tell, how to make every sentence must be correlated, and how to use sentence pattern. Byrne (1983: 39) says that it is important for the beginners to learn in the form of guided writing in order to lead them gradually toward free writing.

Based on some researchers, writing is one of the difficult skills. This opinion is supported by Fadloeli (1986: 11) who says that writing is difficult skill, when we write we seem to communicate into space, we don't know who is receiving the message. It means that we need some points in writing in order to produce a clear and understandable piece of writing for the readers. The points are how to organize what we are going to tell, how to make every sentence must be correlated, and how to use sentence pattern. In line with this idea, at the beginning level, the techniques and procedures of the teaching composition concentrate on 


\section{Afief Fakhruddin ${ }^{* 1}$, Eka Nurhidayat ${ }^{* 2}$ \\ STUDENTS' PERCEPTION ON QUIZZIZ AS GAME BASED LEARNING IN LEARNING GRAMMAR IN WRITTEN DISCOURSE}

the correct language form, the mechanical punctuation and content organization. For teaching correct language form, guided composition has several advantages such as: it can only make sequencing and grading of pattern possible but also the students maximal practice in writing correct form of the language Paulson and Bruder in Fadloeli, (1986:206). It means that the students can express and organizing their idea in writing. In teaching mechanic punctuation, there are two reasons that are needed for students. First, it can help them write readable text or paragraph and the second it helps them understand reading texts. The important thing to remember is that no specific rules in teaching mechanic punctuation (Paultson and Bruder in Fadloeli, 1986: 237). Based on the explanation above, it can bee seen that writing is thinking process. Because of that, the main point in writing a text or paragraph is organizing thought and argument, and then putting them into a coherent and logical whole.

\section{RESEACH METHOD \\ Research Method}

According to Nunan (1992: 3), research is a process of formulating questions, problems, or hypotheses, collecting data or evidence relevant to these questions/ problems/ hypotheses; and analyzing or interpreting it. This means that research is a process that involves; defining a problem, stating an objective, and formulating a hypothesis. It involves gathering information, classification, analysis, and interpretation to determine the extent to which the initial objective has been achieved. According to Nunan (1991: 4), the methodology is to study the practices and procedures used in teaching and the principles and beliefs that underline them. This study employed a qualitative approach, embracing characteristics of a case study to gain an in-depth understanding and reveal the phenomenon of students' perception in Quizizz as Game-Based Learning in learning grammar in Written discourse. The case study is a method of choice when the phenomenon under study is not readily distinguishable from its content. The purpose of such observation is to probe deeply and to analyze intensively the multifarious phenomena that constitute the life cycle of the unit with a view to establishing generalizations about the wider population to which that unit belongs (Blaxter et.al, 2006:71).

Based on the theory above, the researcher made a conclusion that descriptive qualitative method is suitable to be used in this research because suitable with the purpose of the research, that is to get description about student Cohen et al. (2011) stated that this method selected by analysis and interpretation while gathering the data. This study was conducted to describe, explore, and explain the students' perception in Quizizz as Game-Based Learning that was used in learning grammar and students' obstacles in writing the summary of grammatical rules.

\section{Participants}

The participants of the research were 22 English department students of Universitas Majalengka. The data of this research was acquired dependent on the consequences of questionnaires and interviews. The questionnaire was utilized to get data about students' perception towards the execution of Quizizz. The interview was likewise used to get progressively explicit data that can't be gotten 
to by a quesntionnaire. Best (1993: 231) explains there are two forms of questionnaire. They are the closed form and the open form. The closed form is questionnaire that in every item forms have been served an alternative responses and the open form gives an opportunity to the respondents to give a free response in the respondent's own words. In this research, the researcher used the closed form because it is easy to fill out, takes little time, keeps the respondent on the subject, is relatively objectives, and is fairly easy to tabulate and analyze.

\section{FINDINGS AND DISCUSSION Findings}

The researcher used questionnaire to get information from the students about their perception in English especially on the use of the implementation of Quizizz. The questionnaires were given to the students after they had finished in using Quizziz. There were reasons for choosing questionnaire as the instrument. The reasons were follows: it can collect information from a large number of students and on the other side; the students as respondents can complete and return it quickly. The writer wanted to underline here that the questionnaire would be used to measure the students' perception. In analyzing the results of questionnaires, the researcher used Likert Scale. According to Sugiyono (2008: 134), likert scale is a scale of measurement used to measures the attitude, opinion and perception of someone or a group of person about social phenomenon. In the research, this social phenomenon had been appointed specifically by the researcher, and then it can be called as a research variable. By using likert scale, the variable that is measured will spelled out to be variable indicator. At that point this pointer will be made as defining moments to organize instrument things that can be proclamations or questions. In this case, questionnaires were used as an instrument to know the students' English competence. Best (1993: 231) explains there are two forms of questionnaire. They are the closed form and the open form. The closed form is questionnaire that in every item forms have been served an alternative responses and the open form gives an opportunity to the respondents to give a free response in the respondent's own words. In this research, the researcher used the closed form because it is easy to fill out, takes little time, keeps the respondent on the subject, is relatively objectives, and is fairly easy to tabulate and analyze.

There were some steps for data analysis. The first step was to measure the individual students' perception in using quizziz. The researcher computed the data by using the following steps.

This table below is the table of the questionnaire and the results for students perception Toward Quizziz.

Table1.students' perception

\begin{tabular}{|c|l|c|c|c|c|}
\hline No & \multicolumn{1}{|c|}{ Question } & $\begin{array}{c}\text { Strongly } \\
\text { agree }\end{array}$ & Agree & Disagree & $\begin{array}{c}\text { Strongly } \\
\text { disagree }\end{array}$ \\
\hline 1. & Quizziz make me like to learn this course & $81,45 \%$ & $20,45 \%$ & & \\
\hline 2. & $\begin{array}{l}\text { Quizziz help me much to understand the } \\
\text { course }\end{array}$ & $62,70 \%$ & $35,10 \%$ & & \\
\hline 3. & Quizziz make me to enjoy and active & $40,50 \%$ & $55,30 \%$ & & \\
\hline
\end{tabular}




\begin{tabular}{|c|l|c|c|c|c|}
\hline & learning & & & & \\
\hline 4. & Quizziz give me new information & $26,70 \%$ & $50,22 \%$ & & \\
\hline 5. & $\begin{array}{l}\text { Quizziz make me to like learning grammar } \\
\text { in witten discourse }\end{array}$ & $80,30 \%$ & $15,60 \%$ & & \\
\hline 6. & Quizziz help us when leaning in pairs & $26,73 \%$ & $70,21 \%$ & & \\
\hline 7. & Quizziz help me in learning the material & $29,55 \%$ & $60,44 \%$ & & \\
\hline 8. & Quizziz make me happy to learn the couse & $82,89 \%$ & $12,13 \%$ & & \\
\hline 9 & $\begin{array}{l}\text { Quizziz enhance our motivation in learning } \\
\text { grammar in written discourse }\end{array}$ & $74 \%$ & $24 \%$ & & \\
\hline 10 & Quizziz improved my learning & $35,10 \%$ & $47 \%$ & $12,80 \%$ & \\
\hline
\end{tabular}

The table of the survey partitioned into two sections in every classification, and it covers eight inquiries and managed classroom interaction. One sheet of the survey was for one student. From the data, it can be concluded that the writer always gave motivation to the students in order to increase their English competence especially in learning grammar in writen discourse in the classroom. This motivation was very useful for the students because if they had high motivation, they will study seriously. But if they have low motivation they did not study seriously. From the result above, it can be explained that most of the studenrts were strongly agree like English and it can be influence their English competence especially in learning grammar in writen discourse because basically, they had like English lesson. Therefore, when they got grammar in written discourse exercise and did the English exercise in class activity, automatically they will have high motivation to increase English competence. Most of the students often did not found any difficulties in doing the exercises. Based on the result of interview, this happened because they had good motivation when they were doing exercises. Therefore, the writter guide the students in doing the exercises through this aplication. The group of study in classroom activities was very important to increase students' motivation. On the group of study the student demanded to discuss and it can be influential to the students' development in learning English. Most of the students answered strongly agree. It means that the quizziz made an activities groups and individually activities had increased the students' competence in grammar in written discourse. Actually, group activities were very good technique for the students because in this group each student could share with their partner in order to solve the problems being faced. Beside, by made group of study, the student would be more active and it could be increase the student competence. Motivation is a very important thing to raise up our self confidence in studying English. This motivation can come from the teacher, our parents, friends and so on. From the data above, it can be explained that the teacher always gave motivation to the students in order to increase their English competence especially in school environment. This motivation was very useful for the students because if they have high motivation, they will study seriously. But if they had low motivation they did not study seriously. Therefore, the reasercher had to always give motivation to make the student felt interested to do the exercise of grammar in writen discourse. 


\section{DISCUSSION}

\section{Students' perception toward Quizziz as Game-Based Learning as an in learning grammar in Written discourse}

Based on the findings derived from the questionnaire and the interview, The questionnaire method was used besides the test. There were reasons for choosing a questionnaire as the instrument. The researcher used the questionnaire to get information from the students about their English competence, especially in learning grammar in written discourse. In this case, the researcher interviewed some students and their English teacher to get the information about the students' perception throuh this aplication. In this research, the researcher also conducted interview to the students In this case, the researcher interviewed some students to get the information about the students' perception in learning grammar in Written discourse. Students' perception also described in this study. It was in line with Sperling (1982) also affirmed that perception represents peoples' understanding of a present situation in terms of their past experience.

It was found that average of percentage of learning through quizziz on the whole statement, from 22 students, the average of students' answer in percentage related to students' perception the learning process through quizziz in statement number $1.81 \%$ who chose "Strongly agree", $62 \%$ who checklist "Strongly agree", in number two and $82 \%$ who answer "Strongly agree" in the number eigth. From the result of finding, the students' explain their understanding and perception about quizziz. Ten students thought that they feel quizziz make them like to learn the course. Eight students at the same perception that Quizziz make them to like learning grammar in witten discourse.

The result for number two, three, four and six found that some of students chose second option "agree". It can be concluded that when they were learning grammar writen discourse feel enjoy and they were able to focus in the teaching learning process, and also the students felt satisfy after leaning through this aplication.

Based on the data above, It can explaned that the students had a good perception of the implementation of Quizizz. The results showed that the students enjoyed learning grammar through this application; they interested in the learning activity. They can improve their participation when using this application, as stated by student A.: " Quizziz make me like to learn this course, and I can share my opinion with my friends, and I did not shame to speak English when discussing with my group. It can be concluded that most of the students give positive opinion about the implementation of new method in teaching learning activity, using quizziz. Most of students who were taught by using this aplication agreed that their knowledge increased when they shared information with the other students. It was concluded that in quizziz make learning process more effective an effective for the students.

They can get familiar with the material effectively since students with great insight helped students who didn't comprehend the materials yet. Many students can adhere to the guidance that the researcher obtained. Their creavity improved as conceded by students 2: Through this application, I'm happy to learn the couse. What's more, my creativity was improved when we ought to compose inquiries for another gathering. From the result of interview, it can be seen that the aplication always help the student when the students do the exercise about 


\section{Afief Fakhruddin ${ }^{* 1}$, Eka Nurhidayat ${ }^{* 2}$ \\ STUDENTS' PERCEPTION ON QUIZZIZ AS GAME BASED LEARNING IN LEARNING GRAMMAR IN WRITTEN DISCOURSE}

gammar in written discourse. Most of the students said that studying English through this application can increase students ability especially in leaning grammar in Written discourse. In summary, it can be said that the students' low level of motivation, lack of vocabulary, feeling of nervousness and a habit of doing exercises in rush became the problems that the students faced in understanding the material especially when the researcher did no use any aplication.

From explanation above, it could be seen that learnt grammar in writen discouse was not as easy as people imagine. Students faced some difficulties in enriching their grammar. After quizziz was applied the student improved their learnin. It could be seen in the precentage score of perception statement in the table above. The students' could spell English word easily.

\section{CONCLUSION}

In conclusion, the study demonstrated that the majority of the students had positive reactions to the execution of Quizziz in learning grammar. It implies that students experienced and increased numerous beneficial outcomes from the execution of Quizziz as an approach to learn language grammar. It means that students experienced and gained many positive effects from the implementation of Quizziz as a way to learn grammar. It could be concluded that Quizziz offers a positive contribution to education - teaching-learning processes. As Quizziz were provided tools that make the lecturer were creative in creating a material in the teaching-learning courses, it supports face-to-face meeting. From the obtained data, there were not respondents give a negative view of the implementation of Quizziz. They consider previously that learning grammar was a difficult and boring subject. However, after experiencing learning by Quizziz, almost all students respond that teaching-learning grammar via Quizziz was effective, efficient, and interesting. This application can improve students' interest in the learning activity. Most students delighted in and dynamic when learning sentence structure through this application. Additionally, this application can improve students' support in classroom activity since they need to work.

\section{REFERENCES}

Brinton, D. M. (1991). The Use of Media in Language Teaching. In M. Celce Murcia (Ed.), Teaching English as a Second and Foreign Language ( $2^{\text {nd }}$ ed., pp. 454-485). Boston: Heinle \& Heinle Publishers.

Brown, H.D.(1980). Principles of Language Learning And Teaching. New Jersey: Prentice Hall, Inc.

(1994). Teaching by Principles: An Interactive Approach to Language Pedagogy Second Edition. New York: Addison Wesley Longman.

Cohen, L., Manion, L., \& Morrison, K. (2011). Research Methods In Education ( $7^{\text {th }}$ ed.). London: Routledge.

Coulthard, M. (2014). An Introduction to Discourse Analysis. Routledge. 
Gee, J. P., \& Handford, M. (2013). The Routledge Handbook of Discourse Analysis. Routledge.

Glandon, K \& Ulrich, D. 2005. Using Games as a Teaching Strategy, Journal of Nursing Education, 44, pg338-339.

Grabe, W. (1984) Written Discourse Analysis, Annual Review of Applied Linguistics, 5, 101-123.

Haussamen, B. (2003). Grammar Alive! Urbana, IL: National Council of Teachers.

Ke, F. (2014). An Implementation of Design-Based Learning Through Creatin Educational Computer Games: A Case Study on Mathematics Learning During Design and Computing. Computers \& Education, 73, pg26-39.

Mart, C. (2013). Teaching Grammar in Context: Why and How? Theory and Practice in Language Studies, 3(1), 124-129.

McMillan, J., \& Schumacher, S. (2010). Research in Education; Evidence-Based Inquiry (7th ed.). Boston: Person.

Mussen, P. (1973). Psychology: An Introduction. Toronto: D.C. Health and Company.

Muhibbin Syah,(1999).Psikologi Pendidikan Dengan Pendekatan Baru, PT: Remaja Rosda Karya.

Nunan, D.(1992).Research Method in Language Learning. New York; Cambridge University Press.

Prensky, M. (2001). Digital Game-Based Learning. New York, NY: McGraw Hill.

Robbins, S. P., \& Judge, T. A. (2013). Organizational Behavior (15th ed.). New York: Pearson Education.

Shaffer, D. W., Squire, K., Halverson, R., \& Gee, J. P. (2005). Video games and the future of 89 learning. Phi Delta Kappan, 87(2), 104-111.

Sperling, A. P. (1982). Psychology. London: Heinemann.

Steven.(1977). Vocabulary, Semantic and Language Education. New York: Cambridge University Press.

Strumpf, M., \& Douglas, A. (2004). Golden's Concise English Grammar. Kuala Lumpur: Golden Book Centre SDN.

Smedley, D. (1983). Teaching the Basic Skills; Spelling, Punctuation, and Grammar in Secondary English (Teaching Secondary English). London: Methuen \& Co. Ltd.

Thornbury, S. (1999). How to Teach Grammar. Essex: Pearson Education Limited. 
Yanuarti, (2019). Students perception of Snow ball throwing in teaching grammar. Retrieved on $20^{\text {th }}$ june 2020. 